\title{
EFFECT OF PARTIAL OR TOTAL INCLUSION OF BETAINE AND/OR CHOLINE INSTEAD OF ADDED METHIONINE IN BROILER DIETS ON: 2- CARCASS CHARACTERISTICS, SOME BLOOD PARAMETERS AND SENSORY EVALUATION OF MEAT
}

\author{
M.M. El-Shinnawy ${ }^{1}$; Sherif, Kh. El ${ }^{2}$; H. F. A. Motawe ${ }^{3}$ and M. A. Osman ${ }^{3}$ \\ ${ }^{1}$ Animal. Prod. Dept. Fac. Agric., Mansoura Univ. \\ ${ }^{2}$ Poult. Prod. Dept. Fac. Agric., Mansoura Univ. \\ ${ }^{3}$ Regional Center for Food and Feed, Agric. Res. Center, Cairo, Egypt.
}

\section{SUMMARY}

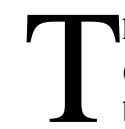

This study was carried out to investigate the effect of partial or total replacement of added DL-methionine (Met) with betaine (BET) or choline or both in diets of broiler chicks on carcass characteristics, some blood parameters and sensory evaluation of meat. A total number of four hundred and forty day-old straight-run Cobb 500 broiler chicks were randomly, weighed and divided into eleven treatments (forty birds each). Each treatment contained four replicates of ten birds. Three basal diets were formulated as controls according to NRC recommendations and used for the starter, grower and finisher phases (0-12 days, $0.165 \%$ added Met.), (12-24 days, $0.135 \%$ added Met.) and (24-36 days, 0.090\% added Met.), respectively. Treatment one was fed the control ration while the other ten treatments were fed the control ration after partial or total replacement of the added Met. with BET, choline or both. The obtained results revealed that replacement of added Met with BET and/or choline positively affected percentages of carcass yield, total edible parts, breast yield and deboned breast meat while those of heart and abdominal fat were decreased but relative weights of giblets, liver and gizzard were not affected compared with their control counterparts. Chicks fed T10 (50\% BET and 50\% choline) and T7 (100\% BET) had significantly higher serum concentrations of glucose, total protein, albumin and globulin when compared the other dietary treatments. On the other hand total cholesterol, triglycerides, ALT, AST, uric acid and creatinine were decreased due to dietary treatments. Acceptance of sensory evaluation was observed with treatment groups. It could be concluded that replacing added Met by BET, choline or both improved carcass yield, total edible parts, breast yield and sensory meat attributes of broiler chicks.

Keywords: methionine, betaine, choline, broiler chickens, carcass characteristics, some of blood parameters, sensory evaluation.

\section{INTRODUCTION}

Methionine, betaine and choline are all sources of labile methyl groups and play an important role in methylation reactions, and the methyl group metabolism of these three compounds is interrelated as illustrated by (Kettunen et al., 2001). Betaine, is a naturally occurring amino acid derivative found in a variety of feedstuffs of plant and animal origin. Betaine has two primary metabolic roles: it is a methyl group donor and it is an osmolyte that assists in cellular water homeostasis (Petronine et al., 1992).

Recently, betaine has been primarily used as a dietary feed supplement in animal nutrition. Betaine has been indicated to have a number of metabolic and physiological roles in poultry nutrition (Kidd et al., 1997). Betaine contains three methyl groups in its structure and donates these in several metabolic reactions. On a molecular weight basis, betaine contains about 3.75 times the methyl groups of methionine and therefore would be an effective compound to spare dietary methionine as a methyl donor. However, the methionine sparing effect of betaine has been the subject of some controversy. Some 


\section{El-Shinnawy et al.}

studies have shown positive responses of animals to betaine supplementation in methionine deficient diets, which included improved animal performance and carcass characteristics (Gao et al., 2006).

Moreover, choline is very important to the poultry species such as broiler, laying hens, ducks, quails etc. Where, choline gives the methyl groups necessary for the formation of methionine from homocysteine through being oxidized to betaine (Zhang et al., 2013). Choline is considered as an essential nutrient in poultry diets. Where, choline plays an indispensable role in several biological processes in the body, including building and maintaining cell structure, primarily as a structural component of phospholipids (Summers, 2013). Therefore, choline has three important metabolic roles, for instance as a constituent of phospholipids, prevent fatty liver through hepatic lipid metabolism and as a precursor for acetylcholine. Acetylcholine is the substance responsible for the transmission of nerve impulses which could not be formed without the presence of choline in the body (Zeisel, 2012). These findings have pointed out to the importance of this nutrient in poultry nutrition and production. It is important for researchers to reinvestigate the use of choline in poultry diets. In the past, several studies have looked at choline and betaine for their methionine sparing effects under ideal conditions (Rafeeq et al., 2011).

Betaine, choline and methionine can serve as sources of methyl (-CH3) groups. It is well understood that choline may acts as a methyl group donor, but in order to function as a methyl group donor, it needs to be converted to betaine in the mitochondria (Rostagno and Pack, 1996). Many studies have examined the interrelationship between betaine and methionine to determine if these compounds can spare the needs of the chick for methionine with considerable variation in results. Virtanen and Rossi (1995) suggested that the response of broiler growth to betaine was greater than that obtained from the addition of methionine. Other studies have failed to demonstrate that the methionine content of the diet could be reduced by supplementation with betaine (McDevitt et al., 2000; El-Ganzory et al., 2004). However, several studies suggested that addition of betaine may improve breast meat yield (McDevitt et al., 2000). Betaine is indirectly involved in the synthesis of carnitine, which is required for transporting long chain fatty acids across the inner mitochondrial membrane for oxidation and therefore, may result in a leaner carcass.

Most commercial poultry diets are deficient in methionine, so there is a need for supplemental methionine in poultry diets. Thus, continued evaluation of methionine is an important part of work toward the balanced diet formulation. In particular, interrelationships of dietary choline, betaine and methionine need to be further explored in poultry at the metabolic level.

In our relevant complementary paper, we have found that growth performance, mortality rate and economic efficiency of broiler chicks were positively affected when added dietary methionine was replaced with betaine, choline or both (Sherif et al. 2017). Therefore, in the present study, an attempt was made to evaluate the effect of dietary inclusion of betaine, choline or both instead of added methionine in broiler diets on carcass characteristics, some blood parameter and sensory evaluation of meat of broiler chicks.

\section{MATERIALS AND METHODS}

\section{Chicks and experimental design:}

The present work was conducted in the Poultry Experimental Station of the Regional Center for Food and Feed (RCFF) located in Nubaria, Alexandria, Egypt during May, 2016. Four hundred and forty day-old straight-run Cobb500 broiler chicks obtained from Dakahlia Poultry Company, Meet Ghamr, ElDakahlia, Egypt, were randomly weighed and divided into eleven dietary treatments as presented in Table 1. Each treatment contained four replicates of ten birds. Birds were kept in battery cages and had free access to feed and water during the experimental period. Water was provided by drip nipples and the broilers were exposed to continuous light ( $24 \mathrm{hrs}$ daily) throughout the experiment. The averages of initial body weights of the different groups were nearly equal.

All chicks were vaccinated against different diseases according to the vaccination programs adopted in most Egyptian broiler farms in Table (2). 


\section{Experimental diets:}

All chemical analyses were performed in the laboratories of the Regional Center for Food and Feed (RCFF), Agricultural Research Center (ARC), Giza, Egypt. The chemical compositions of yellow corn, soybean meal and corn gluten meal are presented in Table (3)

Table (1): Replacement levels of methionine with betaine, choline or both in the experimental rations

\begin{tabular}{clll}
\hline Treatments & Betaine\% & Choline\% & Methionine\% \\
\hline T1 & 0 & 0 & 100 \\
T2 & 0 & 33 & 66 \\
T3 & 0 & 66 & 33 \\
T4 & 0 & 100 & 0 \\
T5 & 33 & 0 & 66 \\
T6 & 66 & 0 & 33 \\
T7 & 100 & 0 & 0 \\
T8 & 66 & 33 & 0 \\
T9 & 33 & 66 & 0 \\
T10 & 50 & 50 & 0 \\
T11 & 33 & 33 & 33 \\
\hline
\end{tabular}

Table (2): Vaccination program.

\begin{tabular}{lll}
\hline Age(days) & Vaccines & Method used \\
\hline 1 & IB brimer & Eye drop \\
6 & IB+ ND (MA5+Clone30) & $\begin{array}{l}\text { Subcutaneously injected into the lower back } \\
\text { part of the neck }\end{array}$ \\
10 & $\mathrm{H}_{5} \mathrm{~N}_{1}$ & Drinking water \\
13 & Infectious bursal disease (Gumboro D78) & Drinking water \\
17 & IB+ ND (MA5+Clone30) & Drinking water \\
\hline
\end{tabular}

Table (3): Chemical Composition of feed ingredients (\%, on DM basis)

\begin{tabular}{llllllll}
\hline & \multicolumn{7}{c}{ Chemical Composition } \\
\cline { 2 - 8 } & OM & CP & EE & CF & Ash & NFE & ME(Kcal/kg) \\
\hline Yellow corn & 98.5 & 8.9 & 1.4 & 2.7 & 1.5 & 85.5 & 3350 \\
Soybean meal & 94.2 & 47.5 & 3.9 & 7.3 & 5.8 & 35.5 & 2230 \\
Corn gluten meal & 98.2 & 63.5 & 2.5 & 2.1 & 1.8 & 30.1 & 3710 \\
\hline
\end{tabular}

The diets were formulated to meet the nutrient requirements of broiler chicks during starting, growing and finishing periods according to the National Research Council (NRC, 1994). 


\section{El-Shinnawy et al.}

All chicks were fed a starter diet from one to 12 days of age containing $22.77 \% \mathrm{CP}$ and $3026 \mathrm{kcal}$ $\mathrm{ME} / \mathrm{kg}$ diet. From 12 to 24 days of age, the birds were switched to a grower diet containing $21.44 \% \mathrm{CP}$ and $3106.9 \mathrm{kcal} \mathrm{ME} / \mathrm{kg}$ diet. While, during 24 to 36 days of age, chicks were fed a finisher diet containing 20.07\% CP and $3198.6 \mathrm{kcal} \mathrm{ME} / \mathrm{kg}$ diet (Table 4).

The first experimental group of chicks was fed the control ration which contained only methionine while the other ten groups were fed the control diets in which the added methionine was partially or completely replaced by betaine, choline or both. The control diets contained DL-methionine levels of $1.65,1.35$ and $0.9 \mathrm{~g} / \mathrm{kg}$ in starter, grower and finisher periods, respectively. Composition and calculated chemical analysis of the basal diets during the three phases of growth are presented in Table (4).

\section{Carcass characteristics:}

At the end of the experiment (36 days of age), two birds from each replicate were randomly taken and starved for 12 hours, then individually weighed and immediately slaughtered and handheld until complete bleeding to evaluate carcass characteristics. They were defeathered and weighed to get the weight of feathers. The individual weights of carcass with neck, giblets (Liver, empty gizzard and heart) and abdominal fat were estimated and expressed as percent of the live body weight.

The head and shanks were then removed and the carcasses were eviscerated and reweighed to determine the carcass weight.

Table (4): Composition and calculated chemical analysis of basal diets during the starter, grower and finisher periods

\begin{tabular}{llll}
\hline Ingredient & Starter & Grower & Finisher \\
\hline Yellow corn & 56.003 & 55.443 & 58.743 \\
Soybean meal & 28.000 & 28.500 & 24.800 \\
Corn gluten meal & 8.500 & 8.500 & 8.500 \\
Sunflower oil & 3.000 & 3.500 & 4.200 \\
Dicalcium phosphate & 2.000 & 1.850 & 1.700 \\
Limestone & 1.100 & 0.900 & 0.795 \\
Vit. \& Min. Mixture ${ }^{(1)}$ & 0.400 & 0.400 & 0.400 \\
NaCl & 0.400 & 0.400 & 0.400 \\
L-Lysine-HCl & 0.350 & 0.290 & 0.290 \\
DL-Methionine & 0.165 & 0.135 & 0.090 \\
Choline chloride & 0.082 & 0.082 & 0.082 \\
Total & 100.000 & 100.000 & 100.000 \\
Calculated values (\% As-fed basis: NRC, 1994) & & & \\
CP & 22.77 & 21.44 & 20.07 \\
EE & 3.91 & 4.42 & 5.11 \\
CF & 3.73 & 3.75 & 3.56 \\
ME (kcal/kg) & 3026 & 3106.9 & 3198.6 \\
Lysine & 1.360 & 1.230 & 1.130 \\
Methionine & 0.580 & 0.540 & 0.470 \\
Methionine + Cystine & 0.980 & 0.920 & 0.840 \\
Calcium & 0.980 & 0.860 & 0.770 \\
Available P & 0.480 & 0.450 & 0.410 \\
\hline
\end{tabular}

(1)Vitamins - minerals mixture supplied per kg of diet: vit. (A), 12000 I.U.; vit. (D), 2000 I.U; vit. (E), 10 mg; vit. $\left(K_{3}\right), 2 \mathrm{mg}$; vit. $\left(B_{1}\right), 1 \mathrm{mg}$; vit. $\left(B_{2}\right), 5 \mathrm{mg}$; vit. $\left(B_{6}\right), 1.5 \mathrm{mg}$; vit. $\left(B_{12}\right), 10 \mu \mathrm{g}$; Biotin, $50 \mu \mathrm{g}$; Pantothenic acid, 10mg; Niacin, $30 \mathrm{mg}$; Folic acid, $1 \mathrm{mg}$; Manganese, $60 \mathrm{mg}$; Zinc, $50 \mathrm{mg}$; Iron, $30 \mathrm{mg}$; Copper, $10 \mathrm{mg}$; Iodine, 1 $\mathrm{mg}$; Selenium, $0.1 \mathrm{mg}$ and Cobalt, $0.1 \mathrm{mg}$.

The dressing percentage was calculated by using the following equation:

Dressing percentage $=($ Carcass weight in grams / live body weight in gram $) \times 100$. 


\section{Blood serum constituents:}

At the end of experimental period, blood samples were withdrawn from jugular veins of three birds in each group from in test tubes. The collected samples were immediately centrifuged at 3000 r.p.m. for 15 minutes. Serum was separated and stored at $-20 C^{\circ}$ until the time of analysis. Total protein and albumin were determined according to the method of Doumas et al. (1971) and Doumas et al. (1981) and globulin concentration was calculated by the difference between total protein and albumin concentrations.

Albumin/globulin ratio was also calculated. Glucose was determined according to the method of Hyvarinen and Nikkla (1962). Liver function was assessed by measuring the activities of Aspartate amino transferase (AST) and Alanine amino transferase (ALT) as described by Reitman and Frankel (1957), total cholesterol, triglycerides and uric acid (Henry, 1964) and creatinine (Bartels and Bohmer, 1971) were determined calorimetrically using commercial kits.

\section{Sensory evaluation:}

Sensory evaluation is a common and very useful tool in quality assessment of meat products. It makes use of the senses to evaluate the general acceptability and quality attributes of the products.

A sensory panel for the descriptive analysis consisted of 5 assessors experienced in sensory evaluation of different food products. The assessors were selected and trained according to the international standards (ISO, 1993). The sensory evaluation was performed according to a standardized sensory descriptive method (ISO, 1985). The sensory attributes of the boiled chicken meat (breast and thigh) were analyzed. A structured numerical scale was used for evaluation of the intensity of each attribute. The left side of scale corresponding to the lowest intensity of attribute was given a value of 1 , and the right side corresponding to the highest intensity was given a value of 7 . All sessions were conducted in a climate-controlled sensory analysis laboratory equipped with individual booths.

The samples were prepared by placing them in boiled water and boiling them for 30 min (breast) or $25 \mathrm{~min}$ (thigh). The samples were quartered lengthwise and served immediately to panelists along with room temperature water, tea and white bread for neutralization of receptors. The assessors were instructed to clean the palate with water or tea between evaluations of individual samples. The following characteristics were assessed: intensity of aroma, taste, tenderness, color, chewiness, juiciness and overall acceptability. The sample order of presentation to each assessor was randomized.

\section{Statistical analyses}

Data from all response variables were subjected to one way analysis of variance applying SAS program (SAS, 2004) using General Liner Model. Significant difference among treatment means were separated using Duncan's multiple range procedure (Duncan, 1955) at 5\% probability.

\section{RESULTS AND DISCUSSION}

\section{Carcass characteristics:}

Table (5) shows the effect of feeding diets in which added methionine was partially or totally replaced with betaine, choline or both on carcass characteristics for the chicks slaughtered at 36 days of age. The results obtained indicated that feeding the diets containing betaine or choline instead of added methionine positively affected carcass yield of 36-days-old broiler chicks compared with their control group .The highest carcass yield was achieved by chicks fed T7 (100\% betaine) and T10 (50\% betaine and $50 \%$ choline) when compared with other dietary treatments, followed by those fed the diet containing $33 \%$ betaine and $66 \%$ choline in place of added methionine, and then those fed the diet containing $100 \%$ choline in place of added methionine in a descending order, respectively. 


\section{El-Shinnawy et al.}

The corresponding values for percentages of total edible parts ranged between (carcass yield + giblets weight) percentages 75.18 and $76.98 \%$, where the highest values of chicks were fed on $100 \%$ betaine while the lowest values were achieved by that chicks were fed T2 (33\% choline and $66 \%$ methionine) and the differences were significant $(\mathrm{P}<0.05)$ compared with the control group.

On the other hand, the results showed that the complete replacement of methionine with betaine or with $66 \%$ betaine and $33 \%$ choline led to a significant increase in relative weights of abdominal fat, breast yield and thigh yield $(\mathrm{p}<0.05)$ than other treatments and the control.

Several studies suggested that addition of betaine may improve breast meat yield (Schutte et al., 1997; McDevitt et al., 2000). Attia et al. (2005) indicated that betaine supplementation significantly improved the percentage of carcass yield in chicks. Similar observations have been reported by Nofal et al. (2014) who stated that dietary supplementation with betaine improved carcass yield, breast and giblets percentages than the control group .

Our results are in concordance with the findings of Jahanian and Rahmani (2008) and Neoh and $\mathrm{Ng}$ (2012), who reported that dietary betaine supplementation improved carcass yield and breast percentage as well as decreased abdominal fat. Similar observation was reported Vitanen and Rosi (1995), who found that added dietary betaine was more efficient than DL-Methionine in supporting breast meat yield.

These results may be due to the function of betaine which can increase breast meat percentage via its primary metabolic roles, firstly as a methyl group doner and secondly as an osmolyte that assists cellular water homeostasis (konca et al., 2008). In this regard, Hammer and Baltz (2002) reported that betaine is considered to be the most effective osmoprotectant among other organic osmolytes such as glycine and glutamine.

The obtained results are in contrast with those stated by Lukic et al. (2012), who indicated that substitution of added methionine with betaine had no significant differences effects on carcass quality, dressing percentages or the amount of abdominal fat in broiler carcass.

Betaine is indirectly involved in the biosynthesis of carnitine which is required for transporting the long-chain fatty acids across the inner mitochondrial membrane for oxidation (De Ridder and Van Dam, 1975) and therefore, may result in a leaner carcass, which is more attractive by many consumers. As shown in Table 5, percentages of abdominal fat of broilers were significantly $(\mathrm{P}<0.05)$ reduced as a result of dietary supplementation of betaine. The decrease of abdominal fat of broilers fed betaine-supplemented diets in the present study may be due to increased hepatic synthesis of carnitine and enhanced activity of the hormone-sensitive lipase in the abdominal fat, as reported by Zhan et al. (2006). The results obtained are in agreement with those obtained by El-Ganzory et al. (2004), who found no significant variations in broiler liver percentage in response to supplemental betaine. Esteve-Garcia and Mack (2000) suggested that betaine supplementation may improve carcass yield. The present results are consistent with the findings of Zhan et al. (2006). The abdominal fat pad of broilers usually represents a waste product and added dietary betaine may decrease the carcass fat of broilers, as reported by Saunderson and Mackinlay (1990). In the other hand, Suhutte et al. (1997) suggested that betaine has no significant influence on abdominal fat deposition in broiler chickens. This observation is in contrast to the data of Sun et al. (2008), who reported that supplementation of betaine to replace $25 \%$ of total methionine decreased abdominal fat yield, the reported differences in literature reported results could be related to management and environmental conditions.

Although betaine is involved in lipid metabolism, a reduction in carcass fat in poultry as a result of betaine supplementation is not clearly documented and more research is needed to help clarify this issue.

In this respect, Wang et al. (2004) suggested that betaine is more effective in improving carcass quality. These results reflected that methionine and betaine may interact with the lipid metabolism by stimulating the oxidative catabolism of fatty acid via their role in carnitine synthesis, thus offering a potential for reduced carcass fatness in commercial production (Schutte et al., 1997; Konca et al., 2008). These studies indicated that growth of different tissues in broiler chickens responded to betaine supplementation differently.

\section{Blood serum constituents:}

Blood serum constituents of broiler chicks are presented in Table 6. All studied blood serum constituents were significantly affected by dietary replacing added dietary methionine with betaine, choline or both. However, serum total protein and albumin were significantly increased by increasing level of replacing added dietary methionine with betaine, choline or both as compared to the control, while globulin was significantly increased in broiler chicks fed T7 (100\% betaine), T8 (66\% betaine plus 
$33 \%$ choline) and T10 (50\% betaine plus 50\% choline) when compared with other dietary treatments. Albumin / globulin ratio was significantly increased for treatment 10 compared with those fed the control diet, whereas, it was insignificantly higher in broiler chicks fed $100 \%$ betaine or T3 (66\% choline plus $33 \%$ methionine).

These results may be due to the function of betaine which may produce an increase in muscle cell proliferation, or may increase availability of methionine, making it available for protein synthesis rather than being used as a methyl donor (Zhan, 2000). The improvement in serum total protein, albumin and globulin due to replacing added dietary methionine with betaine, choline or both may be an indication to its role as a methyl donor rather than for protein metabolism (Remus et al., 2004). These results are in agreement with those obtained by Matthews and Southern (2000), who found that dietary betaine supplementation increased plasma total protein and albumin of broilers under heat stress. Also, (Rama Rao et al. (2011) reported that betaine supplementation enhanced the concentrations of protein and globulin in serum of broilers.

Triglycerides and total cholesterol were significantly decreased by feeding diets in which added methionine was partially or totally replaced with betaine, choline or both (Table 6). The percent decrease in triglycerides levels were $13.15,13.91$ and $18.98 \%$ for broiler chicks fed $\mathrm{T} 10$ (50\% betaine plus $50 \%$ choline), T7 (100\% betaine) and T3 (66\% choline plus 33\% methionine) respectively, and the percent increase in total cholesterol were $27.60,27.70$ and $30.62 \%$ for broiler chicks fed T10 (50\% betaine plus $50 \%$ choline), T3 (66\% choline plus 33\% methionine) and T9 (33\% betaine plus 66\% choline), respectively as compared to the control. These results may be due to a major role of betaine in lipid metabolism, which was associated with an enhanced synthesis of methylated compounds in liver and muscle such as carnitine and creatine (Zhan et al., 2006). 
Table (5): Effect of partial or complete replacing added dietary methionine with betaine, choline or both on carcass traits of 36-day-old broiler chicks

\begin{tabular}{|c|c|c|c|c|c|c|c|c|c|c|c|}
\hline Items & $\begin{array}{l}\text { Tr. } 1 \\
\text { (control) }\end{array}$ & Tr. 2 & Tr. 3 & Tr. 4 & Tr. 5 & Tr. 6 & Tr.7 & Tr. 8 & Tr.9 & Tr. 10 & $\operatorname{Tr} .11$ \\
\hline Live body weight (g) & $1866.67^{d}$ & $1870.83^{d}$ & $1884.79^{\text {cd }}$ & $1898.54^{\mathrm{c}}$ & $1876.93^{\mathrm{cd}}$ & $1902.92^{\mathrm{c}}$ & $1952.50^{\mathrm{b}}$ & $1926.25^{\mathrm{bc}}$ & $1911.04^{\mathrm{bc}}$ & $1980.45^{\mathrm{a}}$ & $1897.12^{\mathrm{c}}$ \\
\hline \multicolumn{12}{|l|}{ Carcass traits $(\%)$} \\
\hline Carcass yield & $70.97^{\mathrm{cd}}$ & $70.68^{\mathrm{d}}$ & $71.08^{\mathrm{cd}}$ & $72.41^{b}$ & $71.56^{\mathrm{c}}$ & $71.73^{\mathrm{c}}$ & $73.04^{\mathrm{a}}$ & $72.36^{\mathrm{bc}}$ & $72.44^{b}$ & $72.86^{\mathrm{ab}}$ & $72.35^{\mathrm{bc}}$ \\
\hline Liver & $2.22^{\mathrm{a}}$ & $2.18^{\mathrm{a}}$ & $2.08^{\mathrm{bc}}$ & $2.12^{\mathrm{b}}$ & $2.04^{\mathrm{c}}$ & $1.96^{\mathrm{cd}}$ & $1.92^{\mathrm{d}}$ & $2.08^{\mathrm{bc}}$ & $2.16^{\mathrm{ab}}$ & $1.90^{\mathrm{d}}$ & $2.10^{\mathrm{b}}$ \\
\hline Gizzard & $1.78^{\mathrm{b}}$ & $1.80^{\mathrm{ab}}$ & $1.70^{\mathrm{bc}}$ & $1.80^{\mathrm{ab}}$ & $1.64^{\mathrm{cd}}$ & $1.82^{\mathrm{a}}$ & $1.60^{\mathrm{d}}$ & $1.68^{\mathrm{cd}}$ & $1.72^{\mathrm{bc}}$ & $1.58^{\mathrm{d}}$ & $1.74^{\mathrm{bc}}$ \\
\hline Heart & $0.48^{\mathrm{b}}$ & $0.52^{\mathrm{ab}}$ & $0.42^{\mathrm{d}}$ & $0.48^{\mathrm{b}}$ & $0.56^{\mathrm{a}}$ & $0.46^{\mathrm{bc}}$ & $0.42^{\mathrm{d}}$ & $0.52^{\mathrm{ab}}$ & $0.46^{\mathrm{bc}}$ & $0.44^{\mathrm{cd}}$ & $0.48^{\mathrm{b}}$ \\
\hline Giblets & $4.48^{\mathrm{a}}$ & $4.50^{\mathrm{a}}$ & $4.20^{\mathrm{c}}$ & $4.40^{\mathrm{ab}}$ & $4.24^{\mathrm{bc}}$ & $4.24^{\mathrm{bc}}$ & $3.94^{\mathrm{d}}$ & $4.28^{\mathrm{bc}}$ & $4.34^{\mathrm{b}}$ & $3.92^{\mathrm{cd}}$ & $4.32^{\mathrm{b}}$ \\
\hline Total edible parts & $75.45^{\mathrm{cd}}$ & $75.18^{\mathrm{d}}$ & $75.28^{\mathrm{d}}$ & $76.81^{\mathrm{ab}}$ & $75.80^{\mathrm{c}}$ & $75.97^{\mathrm{bc}}$ & $76.98^{\mathrm{a}}$ & $76.64^{\mathrm{b}}$ & $76.78^{\mathrm{ab}}$ & $76.78^{a b}$ & $76.67^{\mathrm{b}}$ \\
\hline Abdominal fat & $1.77^{\mathrm{a}}$ & $1.67^{\mathrm{b}}$ & $1.72^{\mathrm{ab}}$ & $1.62^{\mathrm{bc}}$ & $1.58^{\mathrm{c}}$ & $1.48^{\mathrm{cd}}$ & $1.42^{\mathrm{d}}$ & $1.48^{\mathrm{cd}}$ & $1.77^{\mathrm{a}}$ & $1.48^{\mathrm{cd}}$ & $1.63^{\mathrm{bc}}$ \\
\hline Breast yield & $23.44^{\mathrm{d}}$ & $23.41^{\mathrm{d}}$ & $23.87^{\mathrm{cd}}$ & $24.06^{\mathrm{c}}$ & $23.92^{\mathrm{cd}}$ & $24.10^{\mathrm{c}}$ & $25.68^{\mathrm{ab}}$ & $25.30^{\mathrm{b}}$ & $24.96^{\mathrm{bc}}$ & $25.80^{\mathrm{a}}$ & $24.12^{\mathrm{c}}$ \\
\hline Deboned breast meat & $17.74^{\mathrm{d}}$ & $17.75^{\mathrm{d}}$ & $18.48^{\mathrm{cd}}$ & $18.73^{\mathrm{c}}$ & $18.97^{\mathrm{c}}$ & $19.32^{\mathrm{bc}}$ & $21.04^{\mathrm{a}}$ & $20.04^{b}$ & $20.06^{\mathrm{b}}$ & $20.80^{\mathrm{ab}}$ & $19.28^{\mathrm{bc}}$ \\
\hline Thigh yield & $24.62^{\mathrm{d}}$ & $24.54^{\mathrm{d}}$ & $25.16^{\mathrm{bc}}$ & $25.08^{\mathrm{c}}$ & $24.88^{\mathrm{cd}}$ & $25.36^{\mathrm{b}}$ & $25.57^{\mathrm{ab}}$ & $25.04^{\mathrm{c}}$ & $25.68^{\mathrm{a}}$ & $25.68^{\mathrm{a}}$ & $25.36^{\mathrm{b}}$ \\
\hline
\end{tabular}

$a, b, c, d$ Means at the same row with different superscripts are significantly $(P<0.05)$ different. 
Carnitine stimulates to the transport of long-chain fatty acids across the inner membrane of mitochondria where fatty acid oxidation takes place and its ability to regulate fat metabolism (Wang et al., 2004). In addition, the increased hormone-sensitive lipase activity (Zhan et al., 2006) following dietary replacing added methionine with betaine, choline or both perhaps resulted in reducing lipid deposition (Eklund et al., 2005). These results are in agreement with those obtained by Jahanian and Rahmani (2008), and Su et al.(2009) who found that betaine enhanced hormone-sensitive lipase activity and decreased the concentration of plasma triglycerides and cholesterol in broilers and geese compared with control under hot summer condition.

On the other hand, liver enzymes (ALT and AST) were significantly decreased by replacing added methionine with betaine, choline or both as compared to the control. These results are similar to those obtained by Attia et al., (2005), who reported that supplementing 1.0 or $2.0 \mathrm{~g}$ betaine / $\mathrm{kg}$ broiler diet during the starter-grower period (1-56 days of age) resulted in a significant decrease in serum alanine amino transaminase, whereas, Zayed (2012) reported that liver enzymes (AST and ALT) were insignificantly decreased due to betaine supplementation to turkey diet.

Dietary treatments had a slight significant effect on serum glucose concentration when compared to that of their control birds. It is worth noting that blood serum levels of glucose, reported in this study, were in the normal range $(180-250 \mathrm{mg} / \mathrm{dl})$ that previously reported by Bounous et al. (2000). However, Zou and $\mathrm{Lu}$ (2002) stated that betaine supplementation induced a significant increase in serum glucose in laying hens.

\section{Sensory evaluation:}

The effects of replacing added dietary methionine with betaine, choline or both on the means of sensory characteristics (aroma, taste, tenderness, color, chewiness, juiciness and overall acceptability) of chicken breast meat samples are shown in Table 7. There were significant differences between control and groups T10 (50\% betaine plus 50\% choline), T7 (100\% betaine), T8 ( $66 \%$ betaine plus $33 \%$ choline) and T11 (33\% betaine plus 33\% choline plus 33\% methionine) with respect to overall acceptability attribute $(\mathrm{p} \leq 0.05)$, with the lowest value was displayed for birds given the T2 $(33 \%$ choline plus $66 \%$ methionine) (7.21) which was considered as the least acceptable for panelists. While T10 group (7.82) was considered as the most acceptable statistically. While means of sensory characteristics of chicken thigh meat samples were significantly different between control and other experimental groups where the highest overall acceptability values were recorded for the T10 (50\% betaine plus 50\% choline), T7 (100\% betaine) and T9 (33\% betaine plus $66 \%$ choline), with the lowest values for T1 (100\% methionine) which was considered as the least acceptable for panelists. The acceptability of all attributes studied ranged between 'like slightly' to 'like moderately'.

In conclusion, partial or complete replacing added dietary methionine with different levels of betaine, choline or both had a positive effect on carcass characteristics, sensory attributes of meat and improved breast meat yield. Further experimentation on the subject may be carried out to establish the fact that added dietary methionine can be partly or totally replaced by other available analogues. 

Table (6): Effect of partial or complete replacing added dietary methionine with betaine, choline or both on concentrations of some blood serum constituents of 36day-old broiler chicks

\begin{tabular}{|c|c|c|c|c|c|c|c|c|c|c|c|}
\hline Item & $\begin{array}{l}\text { Tr. } 1 \\
\text { (control) }\end{array}$ & Tr. 2 & Tr. 3 & Tr. 4 & Tr. 5 & Tr. 6 & Tr.7 & Tr. 8 & Tr. 9 & Tr. 10 & Tr. 11 \\
\hline Total cholesterol (mg/dl) & $137.13^{\mathrm{a}}$ & $121.47^{\mathrm{c}}$ & $119.10^{\mathrm{cd}}$ & $123.44^{\mathrm{bc}}$ & $128.78^{\mathrm{ab}}$ & $121.00^{\mathrm{c}}$ & $118.06^{\mathrm{cd}}$ & $124.00^{\mathrm{b}}$ & $121.38^{\mathrm{c}}$ & $111.10^{\mathrm{d}}$ & $129.02^{\mathrm{ab}}$ \\
\hline Triglycerides (mg/dl) & $48.14^{\mathrm{a}}$ & $42.40^{\mathrm{ab}}$ & $34.80^{\mathrm{cd}}$ & $42.18^{\mathrm{ab}}$ & $42.00^{\mathrm{b}}$ & $41.60^{\mathrm{b}}$ & $33.04^{\mathrm{d}}$ & $35.01^{\mathrm{cd}}$ & $34.86^{\mathrm{cd}}$ & $33.40^{\mathrm{d}}$ & $40.40^{\mathrm{bc}}$ \\
\hline Glucose (mg/dl) & $198.13^{\mathrm{d}}$ & $206.08^{\mathrm{b}}$ & $208.40^{\mathrm{a}}$ & $204.64^{\mathrm{bc}}$ & $201.76^{\mathrm{cd}}$ & $201.00^{\mathrm{cd}}$ & $206.60^{\mathrm{ab}}$ & $205.00^{\mathrm{bc}}$ & $200.87^{\mathrm{cd}}$ & $205.04^{\mathrm{bc}}$ & $207.00^{\mathrm{ab}}$ \\
\hline Total protein $(\mathrm{g} / \mathrm{dl})$ & $3.45^{\mathrm{d}}$ & $3.47^{\mathrm{d}}$ & $4.02^{\mathrm{bc}}$ & $4.26^{\mathrm{ab}}$ & $3.88^{\mathrm{cd}}$ & $3.90^{\mathrm{cd}}$ & $4.56^{\mathrm{a}}$ & $4.54^{\mathrm{a}}$ & $4.26^{\mathrm{ab}}$ & $4.29^{\mathrm{ab}}$ & $4.11^{\mathrm{b}}$ \\
\hline Albumin (AL), (g/dl) & $1.65^{\mathrm{d}}$ & $1.65^{\mathrm{d}}$ & $2.04^{\mathrm{bc}}$ & $2.12^{\mathrm{b}}$ & $1.90^{\mathrm{cd}}$ & $1.92^{\text {cd }}$ & $2.38^{\mathrm{a}}$ & $2.26^{\mathrm{ab}}$ & $2.04^{\mathrm{bc}}$ & $2.31^{\mathrm{ab}}$ & $1.98^{\mathrm{c}}$ \\
\hline Globulin (GL), (g/dl) & $1.80^{\mathrm{d}}$ & $1.82^{\mathrm{d}}$ & $1.98^{\mathrm{c}}$ & $2.14^{\mathrm{bc}}$ & $1.98^{\mathrm{c}}$ & $1.98^{\mathrm{c}}$ & $2.18^{\mathrm{b}}$ & $2.28^{\mathrm{a}}$ & $2.22^{\mathrm{ab}}$ & $1.98^{\mathrm{c}}$ & $2.13^{\mathrm{bc}}$ \\
\hline AL/GL ratio & $0.92^{\mathrm{d}}$ & $0.91^{\mathrm{d}}$ & $1.03^{\mathrm{b}}$ & $0.99^{\mathrm{bc}}$ & $0.96^{\mathrm{c}}$ & $0.97^{\mathrm{bc}}$ & $1.09^{\mathrm{ab}}$ & $0.99^{b c}$ & $0.92^{\mathrm{d}}$ & $1.17^{\mathrm{a}}$ & $0.93^{\mathrm{d}}$ \\
\hline ALT (U/L) & $145.18^{\mathrm{a}}$ & $142.30^{\mathrm{b}}$ & $136.22^{\mathrm{cd}}$ & $142.40^{\mathrm{b}}$ & $138.50^{\mathrm{bc}}$ & $137.40^{\mathrm{c}}$ & $135.21^{\mathrm{d}}$ & $136.20^{\mathrm{cd}}$ & $136.00^{\mathrm{cd}}$ & $143.76^{\mathrm{ab}}$ & $138.42^{\mathrm{bc}}$ \\
\hline AST (U/L) & $10.75^{\mathrm{a}}$ & $9.25^{\mathrm{bc}}$ & $8.80^{\mathrm{cd}}$ & $9.08^{\mathrm{bc}}$ & $10.04^{\mathrm{ab}}$ & $9.75^{\mathrm{b}}$ & $8.50^{\mathrm{d}}$ & $8.80^{\mathrm{cd}}$ & $9.00^{c}$ & $8.42^{\mathrm{d}}$ & $9.10^{\mathrm{bc}}$ \\
\hline Uric acid (mmol/L) & $6.65^{\mathrm{a}}$ & $5.28^{\mathrm{d}}$ & $6.18^{\mathrm{ab}}$ & $5.75^{\mathrm{bc}}$ & $6.26^{\mathrm{ab}}$ & $5.55^{\mathrm{c}}$ & $5.73^{\mathrm{bc}}$ & $5.75^{\mathrm{bc}}$ & $6.00^{\mathrm{b}}$ & $5.50^{\mathrm{cd}}$ & $5.73^{b c}$ \\
\hline Creatinine $(\mathrm{mg} / \mathrm{dl})$ & $0.38^{\mathrm{a}}$ & $0.25^{\mathrm{cd}}$ & $0.26^{\mathrm{cd}}$ & $0.28^{\mathrm{bc}}$ & $0.31^{\mathrm{ab}}$ & $0.25^{\mathrm{cd}}$ & $0.25^{\mathrm{cd}}$ & $0.30^{\mathrm{b}}$ & $0.28^{\mathrm{bc}}$ & $0.26^{\mathrm{c}}$ & $0.21^{\mathrm{d}}$ \\
\hline
\end{tabular}

$a, b, c, d$ Means at the same row with different superscripts are significantly $(P<0.05)$ different. 
Table (7): Effect of partial or complete replacing added dietary methionine with betaine, choline or both on sensory parameters of breast and thigh meat of broiler chicks

\begin{tabular}{|c|c|c|c|c|c|c|c|c|c|c|c|c|}
\hline Item & & $\begin{array}{l}\text { Tr. } 1 \\
\text { (control) }\end{array}$ & Tr. 2 & Tr. 3 & Tr. 4 & Tr. 5 & Tr. 6 & Tr.7 & Tr. 8 & Tr.9 & Tr. 10 & $\operatorname{Tr} .11$ \\
\hline \multirow{2}{*}{ Aroma } & Breast & $6.80^{\mathrm{d}}$ & $6.80^{\mathrm{d}}$ & $6.75^{\mathrm{c}}$ & $6.90^{\mathrm{bc}}$ & $6.95^{b}$ & $7.20^{\mathrm{a}}$ & $7.04^{\mathrm{ab}}$ & $7.20^{\mathrm{a}}$ & $6.90^{\mathrm{c}}$ & $7.20^{\mathrm{a}}$ & $6.90^{\mathrm{bc}}$ \\
\hline & Thigh & $5.96^{\mathrm{d}}$ & $6.10^{\mathrm{cd}}$ & $6.23^{\mathrm{c}}$ & $6.36^{\mathrm{bc}}$ & $6.08^{b}$ & $6.76^{\mathrm{ab}}$ & $6.82^{\mathrm{ab}}$ & $6.12^{\mathrm{a}}$ & $6.60^{\mathrm{b}}$ & $7.00^{\mathrm{a}}$ & $6.90^{\mathrm{a}}$ \\
\hline \multirow{2}{*}{ Taste } & Breast & $7.30^{\mathrm{d}}$ & $7.32^{\mathrm{d}}$ & $7.60^{\mathrm{b}}$ & $7.45^{\mathrm{c}}$ & $7.60^{b}$ & $7.80^{\mathrm{ab}}$ & $8.10^{\mathrm{a}}$ & $7.80^{\mathrm{ab}}$ & $7.45^{\mathrm{c}}$ & $8.14^{\mathrm{a}}$ & $7.82^{\mathrm{ab}}$ \\
\hline & Thigh & $6.80^{\mathrm{d}}$ & $6.84^{\mathrm{d}}$ & $7.04^{\mathrm{cd}}$ & $7.20^{\mathrm{bc}}$ & $7.18^{\mathrm{bc}}$ & $6.95^{\mathrm{cd}}$ & $7.40^{\mathrm{b}}$ & $7.62^{\mathrm{ab}}$ & $7.08^{\mathrm{cd}}$ & $8.00^{\mathrm{a}}$ & $7.12^{\mathrm{c}}$ \\
\hline \multirow{2}{*}{ Tenderness } & Breast & $7.20^{\mathrm{c}}$ & $7.65^{\mathrm{b}}$ & $7.43^{\mathrm{bc}}$ & $7.20^{\mathrm{c}}$ & $7.18^{\mathrm{c}}$ & $6.85^{\mathrm{d}}$ & $7.90^{\mathrm{a}}$ & $7.02^{\mathrm{cd}}$ & $7.20^{\mathrm{c}}$ & $7.80^{\mathrm{ab}}$ & $7.40^{\mathrm{bc}}$ \\
\hline & Thigh & $7.42^{\mathrm{c}}$ & $7.40^{\mathrm{c}}$ & $7.50^{\mathrm{bc}}$ & $7.50^{\mathrm{bc}}$ & $7.12^{\mathrm{d}}$ & $7.80^{\mathrm{a}}$ & $7.67^{b}$ & $7.36^{\mathrm{cd}}$ & $7.70^{\mathrm{ab}}$ & $7.72^{\mathrm{ab}}$ & $7.14^{\mathrm{d}}$ \\
\hline \multirow{2}{*}{ Color } & Breast & $7.43^{\mathrm{b}}$ & $7.40^{\mathrm{b}}$ & $7.37^{\mathrm{bc}}$ & $7.34^{\mathrm{c}}$ & $7.40^{\mathrm{b}}$ & $7.30^{\mathrm{d}}$ & $7.54^{\mathrm{ab}}$ & $7.50^{\mathrm{ab}}$ & $7.36^{\mathrm{bc}}$ & $7.76^{\mathrm{a}}$ & $7.30^{\mathrm{d}}$ \\
\hline & Thigh & $6.94^{\mathrm{d}}$ & $7.04^{\mathrm{cd}}$ & $7.30^{\mathrm{b}}$ & $7.10^{\mathrm{c}}$ & $7.12^{\mathrm{c}}$ & $7.32^{b}$ & $7.56^{\mathrm{ab}}$ & $7.20^{\mathrm{bc}}$ & $7.80^{\mathrm{a}}$ & $7.84^{\mathrm{a}}$ & $7.54^{\mathrm{ab}}$ \\
\hline \multirow{2}{*}{ Chewiness } & Breast & $7.28^{\mathrm{d}}$ & $7.30^{\mathrm{d}}$ & $7.28^{\mathrm{d}}$ & $7.40^{\mathrm{c}}$ & $7.42^{\mathrm{c}}$ & $7.50^{\mathrm{bc}}$ & $7.77^{\mathrm{b}}$ & $7.80^{\mathrm{b}}$ & $7.98^{\mathrm{ab}}$ & $8.04^{\mathrm{a}}$ & $7.28^{\mathrm{d}}$ \\
\hline & Thigh & $7.60^{b}$ & $7.54^{\mathrm{bc}}$ & $7.18^{\mathrm{d}}$ & $7.44^{\mathrm{cd}}$ & $7.50^{\mathrm{c}}$ & $7.50^{\mathrm{c}}$ & $7.70^{\mathrm{ab}}$ & $7.14^{\mathrm{d}}$ & $7.70^{\mathrm{ab}}$ & $7.80^{\mathrm{a}}$ & $7.50^{\mathrm{c}}$ \\
\hline \multirow{2}{*}{ Juiciness } & Breast & $7.40^{\mathrm{bc}}$ & $6.80^{\mathrm{d}}$ & $7.20^{\mathrm{c}}$ & $7.12^{\mathrm{cd}}$ & $7.41^{\mathrm{bc}}$ & $7.60^{\mathrm{b}}$ & $8.06^{\mathrm{a}}$ & $7.98^{\mathrm{ab}}$ & $7.40^{\mathrm{bc}}$ & $7.98^{\mathrm{ab}}$ & $8.04^{\mathrm{a}}$ \\
\hline & Thigh & $6.86^{\mathrm{ab}}$ & $7.08^{\mathrm{d}}$ & $7.80^{\mathrm{b}}$ & $7.40^{\mathrm{cd}}$ & $7.40^{\mathrm{cd}}$ & $7.44^{\mathrm{cd}}$ & $7.80^{\mathrm{b}}$ & $7.70^{\mathrm{bc}}$ & $7.40^{\mathrm{cd}}$ & $8.08^{\mathrm{a}}$ & $7.60^{c}$ \\
\hline \multirow{2}{*}{ Overall acceptability } & Breast & $7.24^{\mathrm{d}}$ & $7.21^{\mathrm{d}}$ & $7.27^{\mathrm{cd}}$ & $7.24^{\mathrm{d}}$ & $7.33^{c}$ & $7.38^{\mathrm{c}}$ & $7.74^{\mathrm{ab}}$ & $7.55^{\mathrm{b}}$ & $7.38^{\mathrm{c}}$ & $7.82^{\mathrm{a}}$ & $7.46^{\mathrm{bc}}$ \\
\hline & Thigh & $6.93^{\mathrm{d}}$ & $7.00^{\mathrm{cd}}$ & $7.18^{\mathrm{c}}$ & $7.17^{\mathrm{c}}$ & $7.07^{\mathrm{cd}}$ & $7.30^{\mathrm{bc}}$ & $7.49^{\mathrm{ab}}$ & $7.19^{\mathrm{c}}$ & $7.38^{\mathrm{b}}$ & $7.74^{\mathrm{a}}$ & $7.30^{\mathrm{bc}}$ \\
\hline
\end{tabular}

$a, b, c, d$ Means at the same row with different superscripts are significantly $(P<0.05)$ different. 



\section{REFERENCES}

Attia, Y.A.; R.A. Hassan; M.H. Shehatta and S.B. Abd-EL-Hady (2005) Growth, carcass quality and serum constituents of slow growing chicks as affected by betaine addition to diets containing 2 . different levels of methionine. Int. J. Poultry. Sci., 4 : 856-865.

Bartels, H. and M. Bohemr (1971). Colorimetric determination of creatinine. Clin Chim. Acta, 32: 81-85.

Bounous, D. I.; R. D. Wyatt; P. S. Gibbs; J. V. Kilburn and C.F. Quist (2000). Normal hematologic and serum biochemical reference intervals for juvenile wild turkeys. J. Wildl. Dis., 36(2): 293-296.

De Ridder, J.J.M. and K. Van Dam (1975). Control of choline oxidation by rat liver mitochondria. Biochimica et Biophysica Acta Bioenergetics, 408 : 112-122.

Doumas B.T.; W.A. Watson and H.G. Biggs (1971). Albumin standards and the measurement of serum albumin with bromocresol green Clin. Chim. Acta, 31:87-96.

Doumas, B. T.; D.D. Bayse; R.J. Carter; T. Peters and R. Schaffer (1981). A candidate reference method for determination of total protein in serum. 1. Development and validation. Clin. Chem., 27 (10): 1642- 1650.

Duncan, D. B. (1955). Multiple range and multiple F. tests. Biometrics, 11: 1-42.

Eklund, M.; E. Bauer; J. Wamatu and R. Mosenthin (2005). Potential nutritional and physiological functions of betaine in livestock. Nut. Res. Rev., 18: 31-48 .

El-Ganzory, E.H.; R.A. Hassan and Kout El-Kloub M.E. Moustafa (2004). Effect of betaine and/or sodium sulphate supplementation as a substitute for methionine in chick diets. Egypt. Poult. Sci., 24 : 823-843.

Esteve-Garcia, E. and S. Mack (2000). The effect of DL-methionine and betaine on growth performance and carcass characteristics in broilers. Animal Feed Science and Technology, 87(1/2): 85-93.

Gao, S.L.; C.H. Shao; Y.E. Li and X.Y. Sun, (2006). Effects of different amount of betaine instead of methionine on broilers. Hubei J. Anim. Vet. Sci., 1: 10-11

Hammer, M. A. and J. M. Baltz (2002). Betaine is a highly effective organic osmolyte but does not appear to be transported by established organic osmolyte transporters in mouse embryos. Mol. Reprod. Develop., 62:195-202.

Henry, R.J. (1964). Clinical chemistry. Principles and Technics, Harper and Row Publishers, New York.

Hyvarinen, A. and E. A. Nikkla (1962). Specific determination of blood glucose by O-toluidine. Clin. Chim. Acta., 7: 140-143.

ISO (1985). Sensory analysis - Methodology - General guidance, International Organization for Standardization, Geneva

ISO 1 (1993). Assessors for sensory analysis. Part 1: Guide to the selection, training and monitoring of selected assessors.

Jahanian, R. and H. R. Rahmani (2008). The effect of dietary fat level on the response of broiler chicks to betaine and choline supplements. J. Biol. Sci.; 8(2): 362-367.

Kettunen, H.; S. Peuranen, K. Tiihonen and M.T. Saarinen (2001). Intestinal uptake of betaine in vitro and the distribution of methyl groups from betaine, choline and methionine in the body of broiler chicks. Comp. Biochem. Physol. Part A, 128: 269-278.

Kidd, M.T.; P.R. Ferket and J.D. Garlic (1997). Nutritional and osmoregulatory functions of betaine. World Poultry Science Journal, 53: 125-139. 
Konca, Y.; F. Kirkpinar; S. Mert and E. Yayalak (2008). Effects of betaine on performance, carcass, bone and blood characteristics of broilers during natural summer temperatures. J. Anim. Vet. Adv., 7 (8): 930-937.

Lukic, M.; Z. Jokic; V. Petricevic; Z. Pavlovski; Z. Skrbic and L. Stojanovic (2012). The effect of full substitution of supplemental methionine with betaine in broiler nutrition on production and slaughter results. Biotechnology in Animal Husbandry, 28: 361-368.

Matthews, J.O. and L.L. Southern, (2000). The effect of dietary betaine in Eimeria acervulina infected chicks. Poult. Sci., 79: 60-65.

McDevitt, R.M.; S. Mack and I.R. Wallis (2000). Can betaine partially replace or enhance the effect of methionine by improving broiler growth and carcase characteristics? Br. Poult. Sci., 41 : 463-480.

Neoh, S. B. and L.E. Ng (2012). Betaine HCL improves carcass yield in broilers. In: 23rd Annual Australian Poultry Science Symposium. PP: 69 .

Nofal, M.E.; Magda, A. Galal; S.M.M. Mousa; Doaa M.M. Yassien and A.M.A. Bealsh (2014). Effect of dietary betaine supplementation on productive, physiological and immunological performance and carcass characteristic of growing developed chicks under the condition of heat stress. Egypt. Poult. Sci., 35(1) : 237-259.

NRC; National Research Council (1994). Nutrient Requirements of Poultry. 9th rev. ed.; National Academy Press, Washington, DC.

Petronine, P.G.; E.M. De Angelis; P. Borghetti; A.F. Borghetti and K.P. Wheeler (1992). Modulation by betaine of cellular responses to osmotic stress. Biochem. J., $282: 69-73$.

Rafeeq, M.; T.N. Pasha; N. Rashid; B. Hilal and I. Shahzad (2011). Effect of supplementation of methionine, betaine and choline on the performance of broiler chicken in early life fed methionine deficient ration. J. Anim. Plant Sci., 21(4): 778-780.

Rama Rao, S. V.; M. V. L. N. Raju; A. K. Panda; P. Saharia and G. S. Sunder (2011). Effect of supplementing betaine on performance, carcass traits and immune responses in broiler chicken fed diets containing different concentrations of methionine. Asian-Aust. J. Anim. Sci.; 24(5): 662- 669.

Reitman, S. and S. Frankel (1957). A colorimetric method for the determination of serum glutamic oxalacetic and glutamic pyruvic transaminases. Amer. J. Clin. Path., 28: 56-63.

Remus, J. C.; E.E.M. Pierson and M. Hruby (2004). The evaluation of betaine and enzymes in coccidian challenged broilers, XXII Poultry Congress, Istanbul, Turkey 8-13 June

Rostagno, H.S. and M. Pack (1996). Can betaine replace supplemental Dl-methionine in broiler diets? J. Appl. Poult. Res., 5:150-154.

SAS Institute (2004). SAS /STAT User's Guide. Release 9.1. SAS inst. Inc.; Cary NC.; USA.

Saunderson, C.L. and J. Makinlay (1990). Changes in body-weight, composition and hepatic enzyme activities in response to dietary methionine, betaine and choline levels in growing chicks. Br. J. Nutr., 63: 339-349.

Schutte, J.B.; J. De Jong; W. Smink and M. Pack (1997). Replacement value of betaine for DLmethionine in male broiler chicks. Poult. Sci., 76:321-325.

Sherif, Kh. El.; M.M. El- Shinnawy.; H. F. A. Motawe and M. A. Osman (2017). Effect of partial or total inclusion of betaine and/or choline instead of added methionine in broiler diets on: 1. Growth performance and economic efficiency. J. Anim. Poult. Prod.; Mans. Univ., 8 (6): 135-140.

Su, S.Y.; M.V. Dodson; X.B. Li; Q.F. Li; H.W. Wang and Z. Xie (2009). The effects of dietary betaine supplementation on fatty liver performance, serum parameters, histological changes, methylation 


\section{El-Shinnawy et al.}

status and the mRNA expression level of Spot $14 \alpha$ in Landes goose fatty liver. Comparative Biochemistry and Physiology, Part A 154: 308-314.

Summers, J. D. (2013). Effect of choline or betaine supplementation on broilers exposed to different temperature treatments. M. Sci. Thesis, The University of Tennessee, Knoxville

Sun, H.; W.R. Yang; Z.B. Yang; Y. Wang ; S.Z. Jiang and G.G. Zhang (2008). Effects of betaine supplementation to methionine deficient diet on growth performance and carcass characteristics of broilers. American Journal of Animal and Veterinary Sciences, 3(3): 78-84.

Virtanen, E. and L. Rossi (1995). Effects of betaine on methionine requirement of broilers under various environmental conditions. In : Proc. Australian Poultry Science Symposium, Sydney, Australia, pp. 88-92.

Wang, Y. Z.; Z. R. Xu and J. Feng (2004). The effect of betaine and DLmethionine on growth performance and carcass characteristics in meat ducks. Anim. Feed Sci. Techn.; 116(1/2): 151-159.

Zayed, S.M.A. (2012). Physiological studies on turkeys. M. Sci. Thesis, Fac. Agri., Mansoura Univ., Mansoura, Egypt.

Zeisel, S. H. (2012). A brief history of choline. Ann. Nutr. Metab. 61: 254-258.

Zhan, X.A. (2000). Studies on growth-promoting mechanism of betaine in broiler chickens. Acta Agric. Zhejiangensis, 12: 209-212.

Zhan, X.A.; J.X. Li; Z.R. Xu and R.Q. Zhao (2006). Effects of methionine and betaine supplementation on growth performance, carcase composition and metabolism of lipids in male broilers. British Poult. Sci., 47:576-580.

Zhang, C.X.; M.X Pan; B. Li; L. Wang; X.F. Mo; Y.M. Chen; F.Y. Lin and S.C. Ho (2013). Choline and betaine intake is inversely associated with breast cancer risk: A two stage case control study in China. Cancer Sci., 104(2): 250-258.

Zou, X.T and J.J. Lu (2002). Effect of betaine on the regulation of the lipid metabolism in laying hen. Agric. Sci., China, 5:1043-1049. 
تأثير إدخال البيتايين أوالكولين أوكليهما كلياً أوجزئياً فى علائق كتاكيت اللحم كبدائل للمثيونين المضاف

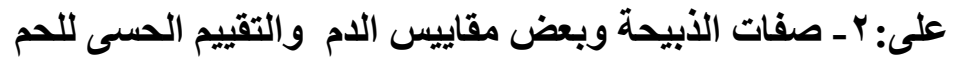

محمد محمد الثناوى' خليل الثحات الخميسى شريف` هادى فتحى عباس مطاوعَ مصطفى أمين عثمانَ 'قسم إنتاج الديوان، كلية الزراعة، جامعة المنصورة، المنصورة

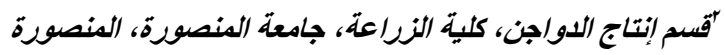
"آلمركز الإقليمي للأغنية والأعلاف ـ مركز البحوث الزيراعيه

تهذف هذه الدراسة إلى تقييم تأثير الإحلال الجزئى أو الكلى للمثيونين المضاف للعليقة بالبيتايين أو الكولين أو كليهما فى علائق

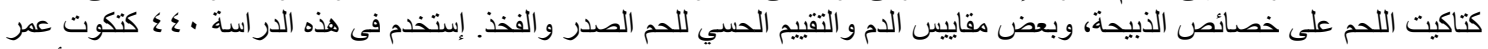

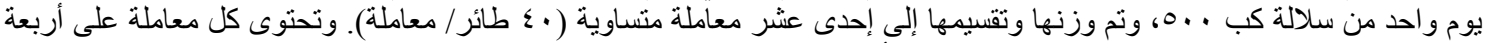

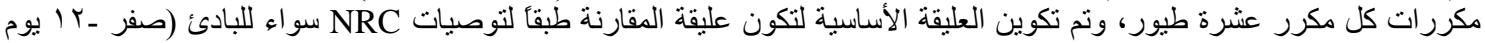

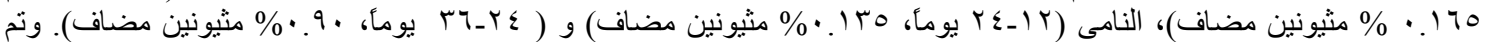

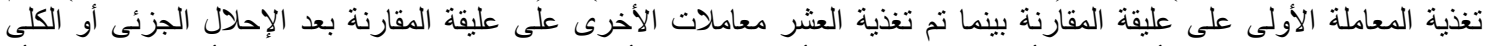

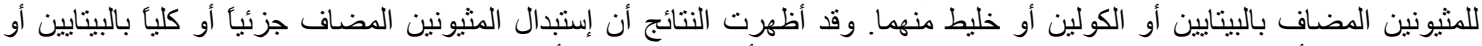

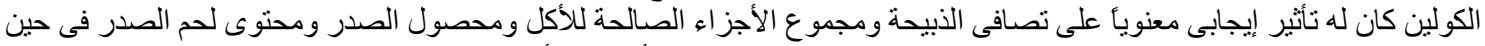

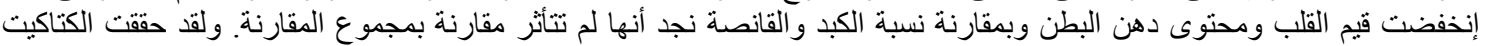

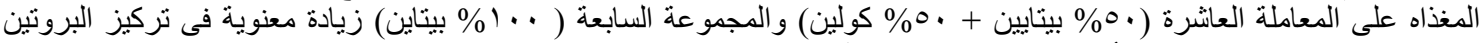

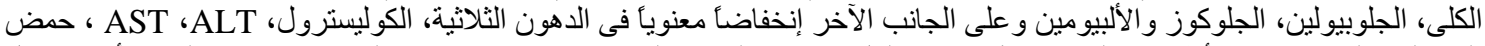

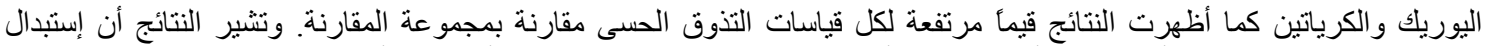

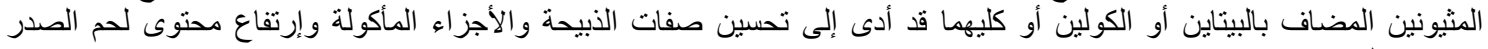

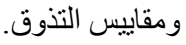

